\title{
Hydrodynamic Interaction Analysis of Floating Multi-body System ${ }^{\dagger}$
}

\author{
Young-Bok Kim ${ }^{1}$, Moo-Hyun kim $^{2}$ Yong Yook Kim ${ }^{3}$ and Young-Hun Kim ${ }^{{ }^{*}}$ \\ ${ }^{1}$ Department of Naval Architecture, Ocean and IT Engineering, Kyungnam University, 449 Weolyung-dong, Changwon-si , \\ Kyungnam-do, 631-701, Korea \\ ${ }^{2}$ Department of Ocean Engineering Division of Civil Engineering, Texas A\&M University, College Station, 77840Texas,USA \\ ${ }^{3}$ Department of Ocean Systems Engineering, Korea Advanced Institute of Science and Technology, 373-1 Guseong-dong, Yusung, \\ Daejon, 305-701 Korea
}

(Manuscript Received September 12, 2011; Revised October 22, 2011; Accepted November 16, 2011)

\begin{abstract}
Recently, several problems have occurred in the space, infra-structure, and facility of the contiguity of existing harbors due to the trend of enlarged container vessels. In this regard, the Mobile Harbor has been proposed conceptually in this study as an effective solution for these problems. The concept is that of a transfer loader that transfers containers from a large container ship to the harbor on land, and is a catamaran type floating barge. The catamaran-type vessel is well known for its advantage in maneuverability, resistance, and effectiveness for working on board. For the safe and effective operation of the two floating bodies (a container ship and the mobile harbor in the near sea detached from the quay), robot arms, novel crane systems, and pneumatic fenders are specially devised with an additional mooring facility or DP (dynamic positioning) system. In this study, this concept is to be verified through comparison and simulation studies under various environmental conditions. It is shown that the proposed concept is in general feasible but there are several areas for further investigation and improvement.
\end{abstract}

Keywords: Mobile harbor, Hydrodynamic interaction, Mooring system, Multi-body interactions, Dynamic positioning system

\section{Introduction}

Due to the recent trend for the enlarged capacity of container ships, it has become more difficult to load/unload in existing container harbors due to the limitation of water depth. As an effective solution to this type of problem, a mobile harbor as a midway loader is proposed in this study. The concept is that the container ships are anchored in the near shore outside the breakwater, and the mobile harbor will approach the container ships for docking in a side-by-side arrangement. Then, the containers are disembarked/embarked from the container ship to the loader and vice versa. Using the mobile harbor with high speed, the containers would be trans-

\footnotetext{
${ }^{\dagger}$ This paper was presented at the OMAE2010 conference, Shanghai, China, June, 2010.

*Corresponding author. Tel.:+82-55-249-2686, Fax.:+82-505-999-2168.

E-mail address: younghun@kyungnam.ac.kr.

Copyright (C) KSOE 2011.
}

ferred to the land in a short period of time. The lack of facilities/infrastructure and the depth limitation of the existing container quays and harbors would be solved in this way. For the effective and rapid transferring of containers, a specially devised crane and docking/mooring system are to be developed.

In this study, hydrodynamic and mooring analyses are performed for two side-by-side ships moored offshore (including the effects of multi-body interactions, the robot arms, mooring lines, and the fenders/hawsers) to verify whether the concept is feasible and to check the levels of dynamic motions and the mooring forces under the various combinations of possible winds, waves, and current. Through this study, the concepts of the mooring devices and the analyzing parameters for container cranes could be delivered as useful design information. 


\section{Principal Design Data}

\subsection{The principal data of the subjected ships}

In this study, the subjected vessels are selected as a 5,000 TEU container ship and the mobile harbor with a catamaran type hull form. For the selection, the capacities, the restoring capabilities, global performance, maneuvera-bilties, and the structural safety are considered. Figs. 1 and 2 show the profiles of the two ships, and the particular data is shown in Table 1 . The data in Table 1 is the information for the initial design stage, and the simple formulas of the radius of gyration are used as follows

$K_{x x}=0.4 B$

$K_{y y}=0.24 L B$

$K_{z z}=0.24 L B P$

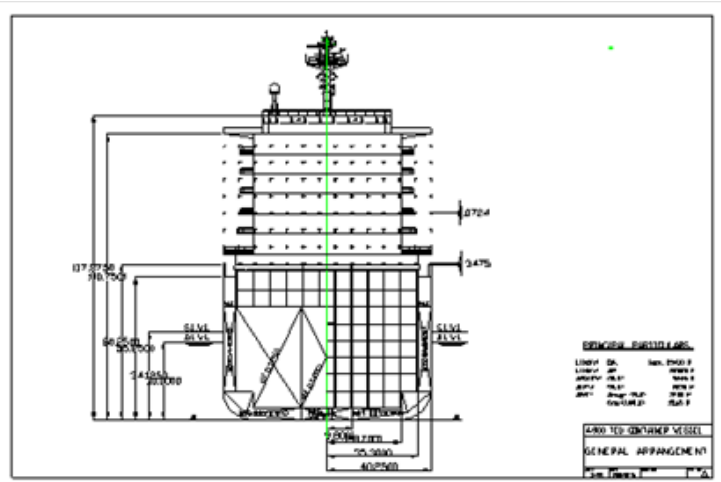

Fig. 1. Forward view of the container ship

\subsection{Environmental data}

The operating condition of the mobile harbor is taken as sea state 3 , which could be encountered in the intended sea area when the container ship is anchored in the near shore. The condition of sea state 3 is summarized and highlighted in yellow in Table 2.
According to the data in Table 2, the significant wave height of $1.25 \mathrm{~m}$, the wave peak frequency of $7.5 \mathrm{sec}$, and the wind speed of 16 knots (abt. 7.15 $\mathrm{m} / \mathrm{s}$ ) are selected for the present analysis. The modified Pierson-Moskowitz spectrum is used for the wave spectrum as shown Fig. 3

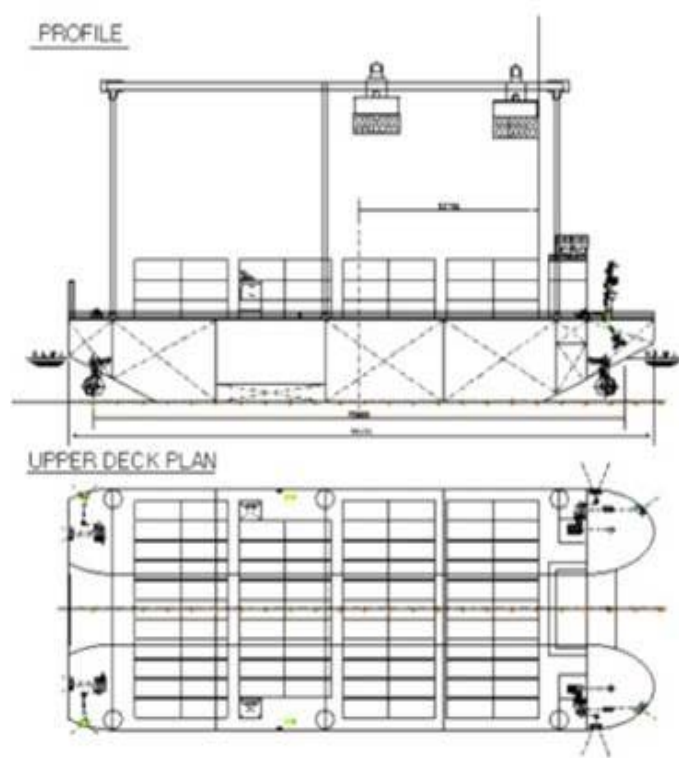

Fig. 2. Forward view of the mobile harbor

Table 1. Particular data of a container ship and the mobile harbor

\begin{tabular}{|c|c|c|c|}
\hline \multicolumn{2}{|c|}{ item } & $\begin{array}{l}\text { STX Container } \\
\text { (5,000 TEU) }\end{array}$ & $\begin{array}{c}\text { Mobile Harbor } \\
\text { (Catamaran) }\end{array}$ \\
\hline \multicolumn{2}{|c|}{ Displacement (Ton) } & 75,797 & $7,469.3$ \\
\hline \multicolumn{2}{|c|}{ LOA (m) } & 294.1 & 76.75 \\
\hline \multicolumn{2}{|c|}{$\operatorname{LBP}(\mathrm{m})$} & 283.0 & 70.0 \\
\hline \multicolumn{2}{|c|}{ Breadth $(\mathrm{mld})(\mathrm{m})$} & 32.2 & 33.0 \\
\hline \multicolumn{2}{|c|}{$\operatorname{Depth}(m l d)(m)$} & 22.1 & 11.0 \\
\hline \multicolumn{2}{|c|}{ Draft(design) (m) } & 12 & 5.3 \\
\hline \multicolumn{2}{|c|}{$\mathrm{Cb}$} & 0.6763 & 0.5976 \\
\hline \multicolumn{2}{|c|}{ KG (m) } & 14.151 & 14.471 \\
\hline \multicolumn{2}{|c|}{ LCB (m) } & -4.294 & 0.402 \\
\hline \multirow{3}{*}{$\begin{array}{c}\text { Radius of } \\
\text { gyration }\end{array}$} & Kxx & 12.88 & 13.2 \\
\hline & Kyy & 67.92 & 16.8 \\
\hline & Kzz & 67.92 & 16.8 \\
\hline
\end{tabular}


Table 2. Environmental conditions depending on the sea state

\begin{tabular}{|c|c|c|c|c|c|c|}
\hline \multirow{3}{*}{$\begin{array}{c}\text { Sea } \\
\text { State } \\
\text { Number }\end{array}$} & \multirow{2}{*}{\multicolumn{2}{|c|}{$\begin{array}{c}\text { Significant Wave } \\
\text { Height(m) }\end{array}$}} & \multirow{2}{*}{\multicolumn{2}{|c|}{$\begin{array}{l}\text { Modal Wave } \\
\text { Period(sec) }\end{array}$}} & \multirow{2}{*}{\multicolumn{2}{|c|}{$\begin{array}{l}\text { Sustained Wind } \\
\text { Speed(knots) }\end{array}$}} \\
\hline & & & & & & \\
\hline & Range & Mean & Range & $\begin{array}{c}\text { Most } \\
\text { Probable }\end{array}$ & Range & Mean \\
\hline $0-1$ & $0-0,1$ & 0,05 & - & - & $0-6$ & 3 \\
\hline 2 & $0,1-0,5$ & 0,3 & $5,1-14,9$ & 6.3 & $7 \sim 10$ & 8,5 \\
\hline 3 & $0,5-1,25$ & 0,88 & $5,3-16,1$ & 7,5 & $11 \sim 16$ & 13,5 \\
\hline 4 & $1.25-2.5$ & 1.88 & $6.1-17.2$ & 8.8 & $17-21$ & 19 \\
\hline
\end{tabular}

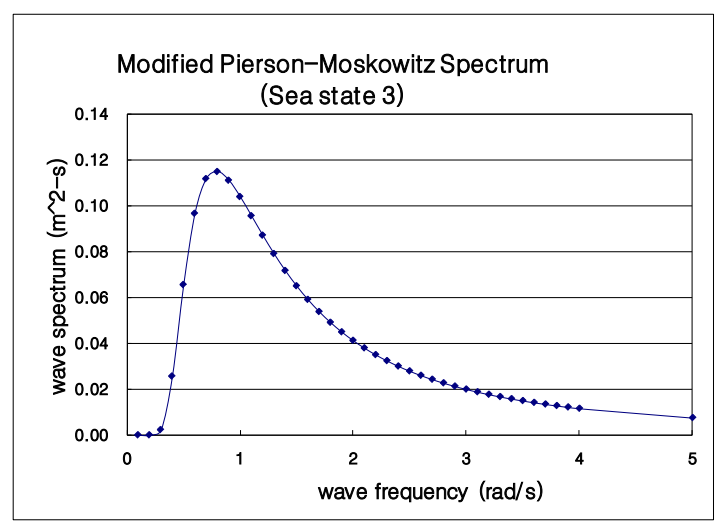

Fig. 3. Pierson-Moskowitz spectrum

(3)
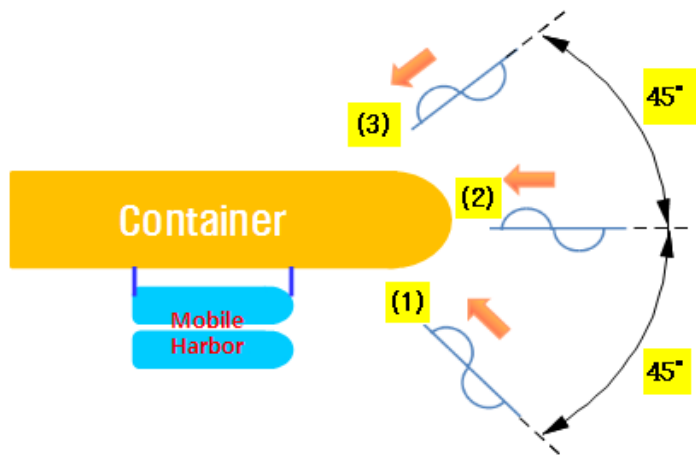

Fig. 4. Directions of combined environmental forces

The modified Pierson-Moskowitz formulae is given by,

$$
S_{\varsigma}(\omega)=A^{\prime} / \omega^{2} e^{-B / \omega^{2}}
$$

where $A^{\prime}=488 H^{2} / T_{n}^{4}, \quad B=1948 / T_{n}^{4}, H$ refers to the significant wave height, and $T_{n}$ is a peak frequency. The wind force, $F_{w}$, is calculated at each time period by using the API wind spectrum (API RP 2T, 1997).

$$
F_{w}=1 / 2 C_{D} \rho_{\text {air }} A_{p} V_{w}^{2}
$$

where $C_{D}$ refers to the drag coefficient by wind, $\rho_{\text {air }}$ denotes the air density, $A_{D}$ is the projected area to be perpendicular to the wind direction, and $V_{w}$ is the wind speed.

The current speed of the target sea area, the near shore outside of the Incheon port where the large container ship can be anchored, is assumed as 0.5 $\mathrm{m} / \mathrm{s}$ uniformly from the free surface to the sea bed.

$F_{C}=1 / 2 C_{c} \rho_{s w} L b p T V_{c}^{2}$

where $C_{c}$ refers to the drag coefficient by current, $\rho_{s w}$ denotes the sea water density, $L b p$ is the length between perpendiculars of the ship, $T$ is the draft of ship, and $V_{c}$ is the current speed.

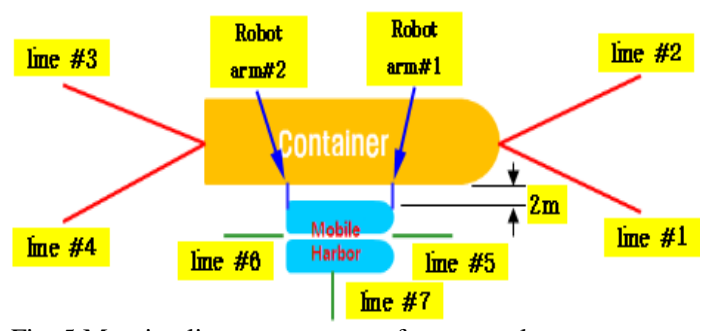

Fig. 5 Mooring line arrangement of two vessels

Table 3. Mooring line properties installed on two vessels

\begin{tabular}{|c|c|c|c|c|c|c|}
\hline \multirow{2}{*}{ Items } & $\begin{array}{c}\text { Stiffness } \\
(\mathrm{EA})\end{array}$ & $\begin{array}{c}\text { dry } \\
\text { weight }\end{array}$ & $\begin{array}{c}\text { wet } \\
\text { weight }\end{array}$ & $\mathrm{CI}$ & $\mathrm{CD}$ \\
\cline { 2 - 7 } & $\mathrm{N}$ & $\mathrm{kg} / \mathrm{m}$ & $\mathrm{kg} / \mathrm{m}$ & $\mathrm{N} / \mathrm{m}$ & $\mathrm{N} / \mathrm{m}$ \\
\hline \multicolumn{2}{|c|}{ Container ship } & $2.70 \mathrm{E}+08$ & 567.75 & 73.8 & 221 & 380 \\
\hline \multirow{2}{*}{$\begin{array}{c}\text { Mobile } \\
\text { Harbor }\end{array}$} & $\begin{array}{c}\text { Mooring } \\
\text { lines }\end{array}$ & $2.70 \mathrm{E}+06$ & 567.75 & 73.8 & 221 & 380 \\
\cline { 2 - 7 } & robot arm & $1.00 \mathrm{E}+04$ & 20 & 0 & 0 & 0 \\
\hline
\end{tabular}

The container ship is to be stationed by using an SPM (Single Point Mooring) buoy. The two ships would use weathervaning to minimize the environmental loading. However, in certain non-collinear circumstances, quartering wave directions are also possible, as shown in Fig. 4.

\subsection{Mooring Conditions}

The mooring type for two floating bodies, a container ship and a mobile harbor, is a side-by-side arrangement with 2-m gap. For the container ship, both bow and stern mooring lines are assumed to be installed, as shown in Fig.5, although only the bow 
mooring line is used with the SPM buoy for weathervaning. The robot arm mooring devices are connected to the each side of the mobile harbor and the container ship. In the initial modeling of the system, three additional mooring lines(line \# 5 7) are used for stationing the mobile harbor instead of more realistic hawsers/fenders and DP system. The three lines installed in the front, in the aft part, and in the starboard side. The robot arms are to cling to the side shell plate of the container ship to prevent drifting/moving away from the container ship. Its ten-sion/compression capacity is typically smaller than that of hawser lines/fenders. In Fig. 5, the configuration and arrangement of the mooring lines and robot arms is shown. In Table 3, the properties of the mooring lines and the robot arms in the initial design stage are shown.

\section{Analysis results}

\subsection{Calculated Results of Mooring Analyses}

The hydrodynamic coefficients are calcu-lated by using the 3D diffraction/radiation panel program WAMIT (Lee, 2006). The hydrodynamic forces are calculated for head sea and two quartering sea conditions. The time domain force time histories are obtained from the frequency-domain hydrodynamic forces calculated in the range from $0.1 \mathrm{rad} / \mathrm{s}$ to 2.0 $\mathrm{rad} / \mathrm{s}$ with 100 divisions. In Fig.6-7, the nondimensionalized sway added mass and hydrodynamic damping coefficients with/without multibody interaction effects are compared. The nondimensional coefficients are defined in the following formula.

$$
\bar{A}_{i j}=A_{i j} /\left(\rho L^{k}\right)
$$

$\bar{B}_{i j}=B_{i j} /\left(\rho V L^{2}(g / L)^{1 / 2}\right)$

where $A_{i j}$ is the added mass, $B_{i j}$ is the hydrodynamic damping coefficient, - (bar) means nondimensionalization, $\rho$ is the water density, $L$ is the ship length ( $L b p$ ), $V$ is the volume of the ship, g means gravitational acceleration, and $\mathrm{k}$ is 1 for sway. The added mass and damping coefficients of sway, for example, show resonant phenomena around $1.0 \mathrm{rad} / \mathrm{s}$ due to multi-body interaction ef- fects. In the time-domain simulation, three components of forces, the wave exciting force, the wind force, and the drag force due to current, are assumed to be collinear

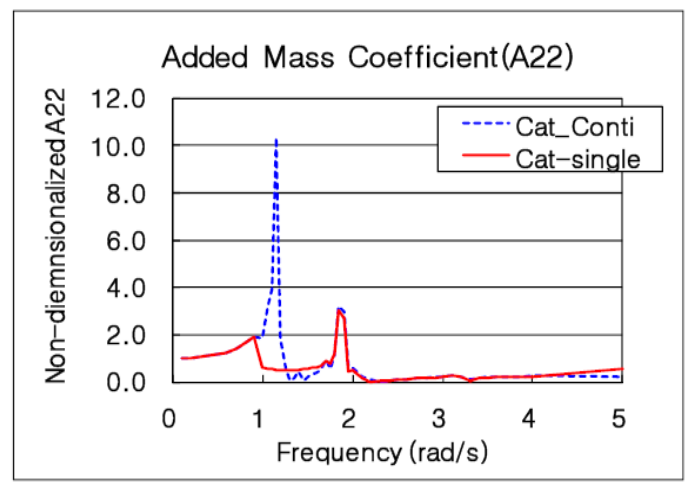

Fig. 6. Comparison of added masses in deep water

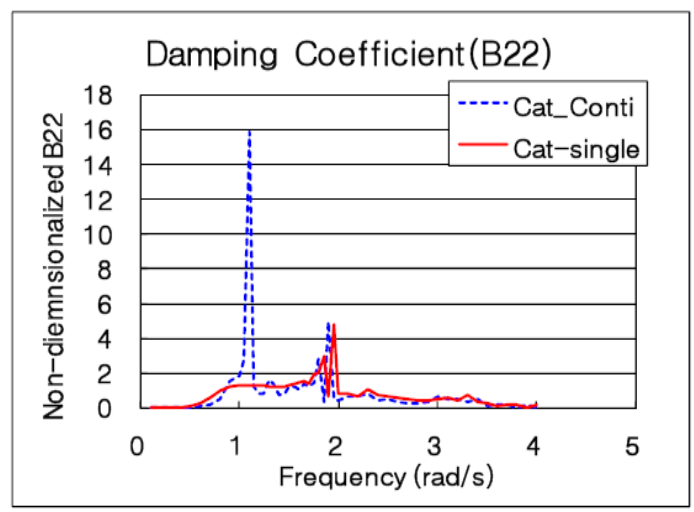

Fig. 7. Comparison of hydrodynamic damping in deep water

Table 5. Design criteria for cranes

\begin{tabular}{|c|c|c|}
\hline \multicolumn{2}{|c|}{ ITEMS } & Mobile Harbor \\
\hline \multirow{3}{*}{ Stability } & Heave limit & $\pm 0.5 \mathrm{~m}$ \\
\cline { 2 - 3 } & $\begin{array}{c}\text { Roll/pitch angle } \\
\text { limit }\end{array}$ & $\pm 5.0^{\circ}$ \\
\hline
\end{tabular}

The criteria for the safe design of cranes on the mobile harbor deck are shown in Table 5. The heave limit and roll/pitch angle limits mean that the floating body does not experience a problem in stability during the crane operation until these upand-down movements and inclinations occur. The calculated motion and mooring results for the deep 
and $25 \mathrm{~m}$ water are summarized in Tables 6-7 and Tables 8-9, respectively. In these tables, the motion responses of the mobile harbor for 135-deg. quartering sea in shallow water are about $30 \%$ larger in roll motion and about $50 \%$ larger in pitch motion than those in the deep water.

Table 6. Motion responses in deep water

\begin{tabular}{|c|c|c|c|c|c|c|c|c|c|c|c|c|}
\hline \multirow{3}{*}{$\begin{array}{l}\text { Motion } \\
\text { Response }\end{array}$} & \multicolumn{12}{|c|}{ Container Ship (5,000 TEU) } \\
\hline & \multicolumn{4}{|c|}{ wave heading $=135^{\circ}$} & \multicolumn{4}{|c|}{$\begin{array}{c}\text { head sea } \\
\end{array}$} & \multicolumn{4}{|c|}{ wave heading $=225^{\circ}$} \\
\hline & mean & $\begin{array}{l}\text { std } \\
\text { dev }\end{array}$ & $\max$ & $\min$ & mean & $\begin{array}{l}\text { std } \\
\text { dev }\end{array}$ & $\max$ & $\min$ & mean & $\begin{array}{l}\text { std } \\
\text { dev }\end{array}$ & $\max$ & min \\
\hline surge $(m)$ & 0.45 & 0.25 & 100 & 0.00 & 0.54 & 0.06 & 0.05 & -0.27 & 0.55 & 0.13 & 1.03 & 0.00 \\
\hline sway(m) & 2.24 & 0.76 & 3.11 & -0.16 & -0.15 & 0.08 & 0.05 & -0.36 & -2.47 & 0.45 & 0.00 & -3.13 \\
\hline heave(m) & -0.01 & 0.06 & 0.17 & -0.18 & -0.01 & 0.03 & 0.08 & -0.10 & -0.01 & 0.05 & 0.16 & -0.19 \\
\hline roll(deg) & -0.10 & 0.40 & 0.83 & -1.06 & -0.01 & 0.01 & 0.02 & -0.05 & 0.15 & 0.83 & 1.97 & -1.75 \\
\hline pitch(deg) & 0.00 & 0.04 & 0.13 & -0.14 & 0.00 & 0.03 & 0.10 & -0.10 & 0.00 & 0.04 & 0.15 & -0.15 \\
\hline yaw(deg) & 0.39 & 0.19 & 0.74 & -0.02 & 0.01 & 0.02 & 0.06 & -0.04 & -0.46 & 0.11 & 0.00 & -0.77 \\
\hline \multirow{3}{*}{$\begin{array}{l}\text { Motion } \\
\text { Response }\end{array}$} & \multicolumn{12}{|c|}{ Mobile Harbor } \\
\hline & \multicolumn{4}{|c|}{ wave heading $=135^{\circ}$} & \multicolumn{4}{|c|}{ head sea } & \multicolumn{4}{|c|}{ wave heading $=225^{\circ}$} \\
\hline & mean & $\begin{array}{l}\text { std } \\
\text { dev }\end{array}$ & $\max$ & $\min$ & mean & $\begin{array}{l}\text { std } \\
\text { dev }\end{array}$ & $\max$ & $\min$ & mean & $\begin{array}{l}\text { std } \\
\text { dev }\end{array}$ & $\max$ & $\min$ \\
\hline surge $(m)$ & 0.00 & -0.25 & 0.82 & -0.86 & -0.07 & 0.14 & 0.44 & -0.59 & 0.05 & 0.05 & 0.23 & -0.13 \\
\hline sway(m) & -41.8 & 0.7 & -40.4 & -43.9 & -41.6 & 6.5 & -40.2 & -43.1 & -42.3 & 71 & -40.5 & -44.1 \\
\hline heave(m) & -0.07 & 0.19 & 0.45 & -0.56 & -0.07 & 0.12 & 0.40 & -0.48 & -0.06 & 0.07 & 0.16 & -0.30 \\
\hline roll(deg) & 0.10 & 1.51 & 4.09 & -4.03 & 0.14 & 0.61 & 193 & -1.74 & 0.14 & 0.85 & 2.62 & -2.29 \\
\hline pitch(deg) & 0.05 & 0.65 & 188 & -1.58 & 0.05 & 0.43 & 192 & -1.84 & 0.04 & 0.11 & 0.44 & -0.33 \\
\hline yaw(deg) & 0.45 & 0.69 & 250 & -1.15 & 0.62 & 0.19 & 0.62 & -0.59 & -0.61 & 0.19 & 0.00 & -1.22 \\
\hline
\end{tabular}

Table 7. Mooring analysis results in deep water

\begin{tabular}{|c|c|c|c|c|c|c|c|c|c|c|c|c|}
\hline \multirow{2}{*}{$\begin{array}{l}\text { Mooring } \\
\text { Tension } \\
\text { Response }\end{array}$} & \multicolumn{4}{|c|}{ wave hesding = $135^{\circ}$} & \multicolumn{4}{|c|}{ head see } & \multicolumn{4}{|c|}{ wave heading = $225^{\circ}$} \\
\hline & mean & $\begin{array}{l}\text { std } \\
\text { dev }\end{array}$ & $\max$ & $\min$ & mean & $\begin{array}{l}\text { std } \\
\text { dev }\end{array}$ & max & $\min$ & mean & \begin{tabular}{|l} 
std \\
dev \\
\end{tabular} & $\max$ & min \\
\hline Une 11 (ton) & 76.3 & 28.1 & 219.8 & 25.4 & 317 & 5.1 & 35.5 & 27.9 & 15.7 & 2.7 & 17.8 & 13.6 \\
\hline Une 12 (ton) & 17.2 & 27 & 27.5 & 15.1 & 34.0 & 5.5 & 38.5 & 29.5 & 79.9 & 21.8 & 258.6 & 26.0 \\
\hline Une 13 (ton) & 23.6 & 3.2 & 35.0 & 18.1 & 31.2 & 5.0 & 35.3 & 27.1 & 70.3 & 19.4 & 202.0 & 26.1 \\
\hline Une 44 (ton) & 68.5 & 27.7 & 230.5 & 25.4 & 28.7 & 4.6 & 32.2 & 25.2 & 22.8 & 4.1 & 31.8 & 13.8 \\
\hline Une $155($ tonn) & 80.3 & 1.5 & 85.2 & 75.7 & 82.1 & 12.8 & 87.2 & 77.0 & \begin{tabular}{|l|l}
79.8 & \\
\end{tabular} & 13.4 & 83.4 & 76.2 \\
\hline Une 15 (ton) & 80.6 & 1.6 & 86.4 & 75.6 & 81.1 & 12.7 & 85.9 & 76.3 & 79.6 & 13.4 & 83.1 & 76.2 \\
\hline Une if (ton) & 37.6 & 2.8 & 44.3 & 29.5 & 35.1 & 5.5 & 37.9 & 32.3 & 30.4 & 5.1 & 33.2 & 27.6 \\
\hline $\begin{array}{l}\text { Robot arm } \theta_{1} \\
\text { (ton) }\end{array}$ & 1.20 & 0.21 & 206 & 0.73 & 1.09 & 0.20 & 152 & 0.67 & 0.70 & 0.14 & 0.96 & 0.5 \\
\hline $\begin{array}{c}\text { Robot arm 12 } \\
\text { (ton) }\end{array}$ & 1.22 & 0.18 & 1.85 & 0.87 & 1.09 & 0.18 & 136 & 0.83 & 0.69 & 0.13 & 0.88 & 0.5 \\
\hline
\end{tabular}

In contrast, the motion responses for 225-deg. quartering sea in the shallow water are about $9 \%$ larger in roll motion and about $7 \%$ larger in pitch motion than those in the deep water. In the mooring analysis results, the mooring tensions in the shallow water are about $4 \sim 6 \%$ larger than those in the deep water.

In the next step, the fender/hawser is modeled as a linear spring element, and two fenders/hawsers are installed by replacing the mooring lines of the mobile harbor as shown in Fig. 8. The stiffness of a fender is assumed to be $1.0 \mathrm{E}+07 \mathrm{~N} / \mathrm{m}$.

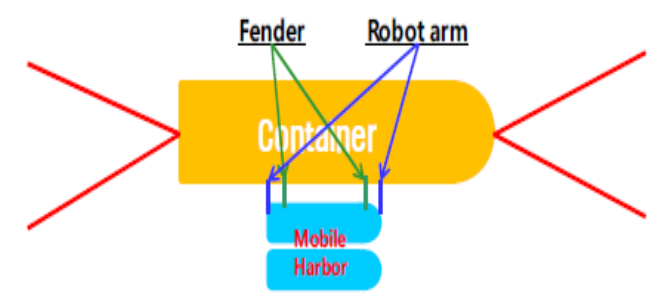

Fig. 8. Two-body model composed of a container ship and the mobile harbor

Table 8. Motion responses in shallow water (water depth $=25 \mathrm{~m}$ )

\begin{tabular}{|c|c|c|c|c|c|c|c|c|c|c|c|c|}
\hline \multirow{3}{*}{$\begin{array}{c}\text { Motion } \\
\text { Response }\end{array}$} & \multicolumn{12}{|c|}{ Container Ship (5,000 TEU) } \\
\hline & \multicolumn{4}{|c|}{ wave heading $=135^{\circ}$} & \multicolumn{4}{|c|}{ head sea } & \multicolumn{4}{|c|}{ wave heading $=225^{\circ}$} \\
\hline & mean & $\begin{array}{l}\text { std } \\
\text { dev }\end{array}$ & $\max$ & $\min$ & mean & $\begin{array}{l}\text { std } \\
\text { dev }\end{array}$ & $\max$ & $\min$ & mean & $\begin{array}{l}\text { std } \\
\text { dev }\end{array}$ & $\max$ & $\min$ \\
\hline surge(m) & 0.54 & 0.14 & 104 & 0.00 & -0.13 & 0.07 & 0.02 & -0.30 & 0.55 & 0.14 & 102 & 0.00 \\
\hline sway(m) & 250 & 0.44 & 322 & 0.00 & -0.16 & 0.15 & 0.18 & -0.56 & -2.50 & 0.43 & 0.00 & -3.19 \\
\hline heave(m) & -0.01 & 0.05 & 0.14 & -0.17 & -0.01 & 0.03 & 0.08 & -0.10 & -0.01 & 0.05 & 0.13 & -0.17 \\
\hline roll(deg) & -0.28 & 0.58 & 128 & -1.84 & -0.03 & 0.03 & 0.05 & -0.10 & 0.16 & 0.54 & 159 & -1.30 \\
\hline pitch(deg) & 0.00 & 0.04 & 0.15 & -0.15 & 0.00 & 0.03 & 0.10 & -0.10 & 0.00 & 0.04 & 0.15 & -0.14 \\
\hline yaw(deg) & 0.45 & 0.11 & 0.84 & 0.00 & 0.01 & 0.05 & 0.12 & -0.11 & -0.46 & 0.11 & 0.00 & -0.79 \\
\hline \multirow{3}{*}{$\begin{array}{l}\text { Motion } \\
\text { Response }\end{array}$} & \multicolumn{12}{|c|}{ Mobile Harbor } \\
\hline & \multicolumn{4}{|c|}{ wave heading $=135^{\circ}$} & \multicolumn{4}{|c|}{ head sea } & \multicolumn{4}{|c|}{ wave heading $=225^{\circ}$} \\
\hline & mean & \begin{tabular}{|l|} 
std \\
dev
\end{tabular} & $\max$ & $\min$ & mean & $\begin{array}{l}\text { std } \\
\text { dev }\end{array}$ & $\max$ & $\min$ & mean & $\begin{array}{l}\text { std } \\
\text { dev }\end{array}$ & $\max$ & $\min$ \\
\hline surge(m) & -0.03 & 0.22 & 0.72 & -0.80 & -0.07 & 0.14 & 0.43 & -0.58 & 0.05 & 0.05 & 0.24 & -0.14 \\
\hline sway(m) & -40.9 & 6.5 & -38.7 & -43.0 & -41.6 & 6.6 & -40.1 & -43.1 & -42.4 & 6.8 & -40.8 & -44.0 \\
\hline heave(m) & -0.07 & 0.19 & 0.62 & -0.74 & -0.07 & 0.12 & 0.41 & -0.48 & -0.06 & 0.07 & 0.14 & -0.29 \\
\hline $\operatorname{roll}(\mathrm{deg})$ & 0.12 & 1.58 & 5.46 & -5.11 & 0.13 & 0.61 & 1.94 & -1.74 & 0.14 & 0.70 & 2.41 & -2.20 \\
\hline pitch(deg) & 0.05 & 0.68 & 2.89 & -2.74 & 0.04 & 0.43 & 1.89 & -1.86 & 0.04 & 0.10 & 0.41 & -0.31 \\
\hline yaw(deg) & 0.37 & 0.62 & 2.40 & -1.66 & 0.02 & 0.22 & 0.77 & -0.71 & -0.58 & 0.16 & 0.00 & -1.17 \\
\hline
\end{tabular}


Table 9. Mooring analysis results in shallow water (water depth $=25 \mathrm{~m}$ )

\begin{tabular}{|c|c|c|c|c|c|c|c|c|c|c|c|c|}
\hline \multirow{2}{*}{$\begin{array}{l}\text { Mbcring } \\
\text { Tersion } \\
\text { Reapcnse }\end{array}$} & \multicolumn{4}{|c|}{ wave heading = $135^{\circ}$} & \multicolumn{4}{|c|}{ head ser } & \multicolumn{4}{|c|}{ wave hading = 225 } \\
\hline & mean & $\begin{array}{l}\text { std } \\
\text { dev }\end{array}$ & $\max$ & $\min$ & $\operatorname{men}$ & $\begin{array}{l}\text { std } \\
\text { dev }\end{array}$ & $\max$ & $\min$ & 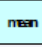 & $\begin{array}{l}\text { std } \\
\text { dev }\end{array}$ & $\max$ & $\min$ \\
\hline line $=1+(t a n)$ & 80.9 & 20 & 233.7 & 0.0 & 26.4 & 44 & 31.2 & 0.0 & 15.8 & 25 & 183 & 0.0 \\
\hline Line $=2(t+n)$ & 15.8 & 25 & 18.6 & 00 & 285 & 4.8 & 34.5 & 0.0 & 81.1 & 20.3 & 2516 & 0.0 \\
\hline Line $=\mathbb{3}(\operatorname{ton})$ & 226 & 40 & 35.2 & 0.0 & 25.5 & 4.3 & 30.3 & 0.0 & 71.5 & 183 & 1861 & 0.0 \\
\hline Line & 71.2 & 19.2 & 190.5 & 0.0 & 23.5 & 3.9 & 284 & 0.0 & 227 & 40 & 33.3 & 0.0 \\
\hline Line $=5$ (ton) & 785 & 126 & 84.5 & 00 & 79.6 & 127 & 84.5 & 0.0 & 800 & 128 & 83.3 & 0.0 \\
\hline Line $46(t+m)$ & 78.5 & 126 & 84.0 & 0.0 & 787 & 126 & 83.5 & 0.0 & 798 & 127 & 83.1 & 0.0 \\
\hline Line $=7 f(t a n)$ & 36.4 & 60 & 42.9 & 00 & 33.3 & 5.3 & 35.6 & 0.0 & 305 & 4.9 & 328 & 0.0 \\
\hline $\begin{array}{c}\text { Robot ammin } 1 \\
\text { (ton) }\end{array}$ & 1.24 & 0.24 & 178 & 0.00 & 0.90 & 0.17 & 1.26 & 0.00 & 0.70 & 0.13 & 0.94 & 0.00 \\
\hline $\begin{array}{l}\text { Pabot amit2 } \\
\text { (ton) }\end{array}$ & 1.23 & 0.25 & 184 & 0.00 & 0.91 & 0.15 & 1.12 & 0.00 & $\alpha \in \theta$ & 0.12 & 0.87 & 0.00 \\
\hline
\end{tabular}

According to the above results, it can be noticed that the surge and yaw responses of the mobile harbor are noticeably increased since there is no resistance in the surge direction with the given arrangement. This example illustrates that the hawser/fender design needs to be carried out with care to provide enough resistance while avoiding dynamic amplification. As shown in Table 11, the statistical data of the calculated mooring tensions on the container ship and robot arm tensions are highlighted. It seems that the surge and yaw motions of the mobile harbor should be reduced by re-adjusting the stiffness of the robot arms and fender/hawser. However, the roll and pitch motions are under the critical level (5 degrees) to ensure the crane operation of the mobile harbor.

Table 10. Motion responses of two ships considering fenders (water depth $=25 \mathrm{~m}$ )

\begin{tabular}{|c|c|c|c|c|}
\hline \multirow{2}{*}{$\begin{array}{c}\text { Motion } \\
\text { responses }\end{array}$} & \multicolumn{4}{|c|}{5,000 TEU Container ship } \\
\cline { 2 - 5 } & mean & $\begin{array}{c}\text { std } \\
\text { dev }\end{array}$ & max & min \\
\hline surge(m) & -0.13 & 0.78 & 1.95 & -2.25 \\
\hline sway(m) & 0.55 & 1.07 & 2.91 & -1.87 \\
\hline heave(m) & -0.01 & 0.02 & 0.07 & -0.09 \\
\hline roll(deg) & -0.50 & 1.62 & 3.09 & -4.49 \\
\hline pitch(deg) & 0.00 & 0.03 & 0.09 & -0.08 \\
\hline yaw(deg) & -0.11 & 0.75 & 1.70 & -1.85 \\
\hline \multirow{2}{*}{$\begin{array}{c}\text { Motion } \\
\text { responses }\end{array}$} & mean & $\begin{array}{c}\text { std } \\
\text { dev }\end{array}$ & max & min \\
\cline { 2 - 5 } & & 7.41 & 17.5 & -19.4 \\
\hline surge(m) & -4.75 & 7.5 & -1.90 \\
\hline sway(m) & 0.57 & 1.07 & 2.95 & -0.60 \\
\hline heave(m) & -0.02 & 0.16 & 0.56 & -2.70 \\
\hline roll(deg) & -0.27 & 0.53 & 1.78 & -2.59 \\
\hline pitch(deg) & 0.01 & 0.60 & 2.44 & -2.59 \\
\hline yaw(deg) & -10.8 & 14.8 & 24.1 & -43.7 \\
\hline
\end{tabular}

Table 11. Mooring analysis results considering fenders (water depth $=25 \mathrm{~m}$ )

\begin{tabular}{|c|c|c|c|c|}
\hline \multirow{2}{*}{$\begin{array}{l}\text { Mooring Line } \\
\text { Tensions }\end{array}$} & \multicolumn{4}{|c|}{ head sea } \\
\hline & mean & $\begin{array}{l}\text { std } \\
\text { dev }\end{array}$ & $\max$ & $\min$ \\
\hline Line \#1 (ton) & 49.4 & 51.7 & 417.2 & 14.8 \\
\hline Line \#2 (ton) & 50.6 & 67.2 & 553.1 & 14.0 \\
\hline Line \#3 (ton) & 35.9 & 43.2 & 415.6 & 13.7 \\
\hline Line \#4 (ton) & 52.1 & 57.4 & 497.2 & 15.0 \\
\hline $\begin{array}{c}\text { Robot arm \#1 } \\
\text { (ton) }\end{array}$ & 14.62 & 11.72 & 63.8 & 0.07 \\
\hline $\begin{array}{c}\text { Robot arm \#2 } \\
\text { (ton) }\end{array}$ & 9.70 & 8.32 & 48.0 & 0.11 \\
\hline $\begin{array}{c}\text { Fender force } \\
\text { (ton) }\end{array}$ & 59.1 & 254.2 & 1,821 & $-1,080$ \\
\hline $\begin{array}{l}\text { Fender mom- } \\
\text { ent (ton-m) }\end{array}$ & $\begin{array}{c}-10.8 \\
(328.5)\end{array}$ & $\begin{array}{c}230.0 \\
(2,230)\end{array}$ & $\begin{array}{c}1,410 \\
(12,050)\end{array}$ & $\begin{array}{c}-1,932 \\
(-20,530\end{array}$ \\
\hline
\end{tabular}

\section{Conclusions}

In this study, the dynamic analyses of the 5,000 TEU container ship and the mobile harbor in a sideby-side arrangement are conducted, considering the two-body interaction effects under various environmental conditions of sea state 3. In this study, the effects of the robot arms that cling to the side shell plate of the larger container ship and fenders/hawsers which are placed in the gap are compared.

In addition, the 6 DOF motions and mooring tensions are compared for two different water depths; deep water and 25-m depth in both head and quartering seas. The results of the shallow water are somewhat higher than those of the deep water. For the two quartering seas of 135 and 225 degrees, the results somewhat differ with each other due to the sheltering effects.

In more realistic conditions with robot arms and fenders/ hawsers, it is revealed that the roll and pitch motions are controlled within the allowable limit to ensure the crane operation of the mobile harbor. However, more studies need to be carried out for a more desirable connection method between the two floating bodies to minimize the surge and yaw motions of the mobile harbor.

\section{Acknowledgements}

The present work is part of the research program on the Development Project of the Fundamental Technology on the Mobile Harbor, supported by the Korea Ministry of Education, Science and Technology and KAIST. 


\section{References}

[1] API RP 2T, Recommended Practice for Planning, Designing, and Consulting Tension Leg Platforms, 2nd Edition, American Petroleum Institute, N.W., Washington D.C. (1997).

[2] Bhattacharyya, R., Dynamics of Marine Vehicles, Wiley \& Sons, USA, (1978).

[3] Kim, M. H., Winpost User's Manual, 3rd ed., Texas A\&M University, College Station, USA, (2000).

[4] Kim, Y. B., Kim, M. H., Hull/Mooring/Riser Coupled Dynamic Analysis of a Turret-Moored FPSO Compared with OTRC Experiment, J. of Ship and Ocean Technology, v.8, no.3, (2004) pp.26-39.

[5] Kim, Y. B., Kim, M. H., Dynamic Analysis of Multiple-Body Floating Platforms Coupled with Mooring Lines and Risers, J. of Ship and Ocean Technology, v.9, no.1, (2005) pp.11-26.

[6] Kwak, H. U., Choi, H. S., Shin, H. S., A Motion Analysis of FPSO in Irregular Waves including Swells , J. of Ship and Ocean Technology, v.9, no.2, (2005) pp.21-28.

[7] Lee, C. H., WAMIT User's Manual, Ver. 6.4, WAMIT, Inc, MA, USA, (2006).

[8] OCIMF, Prediction of Wind and Current Loads on VLCCs, 2nd Edition, Witherby \& Co. Ltd, London, England, (1994).

[9] Wichers, J.E.W., A Simulation Model for a Single Point Moored Tanker, Ph.D. Dissertation, Delft University of Technology, Delft, The Netherlands, (1988). 